\title{
PENGARUH LATIHAN (ROM) PASIF TERHADAP KEKUATAN OTOT EKSTREMITAS PADA PASIEN STROKE DI RUANG RA4 RSUP H. ADAM MALIK MEDAN TAHUN 2014
}

\author{
Zainuddin Harahap \\ Jurusan Keperawatan Poltekkes Kemenkes Medan
}

\begin{abstract}
Abstrak
Stroke merupakan syndrom klinis yang awal timbulnya mendadak, progresif, berupa defisit neurologis fokal dan atau global yang berlangsung 24 jam atau lebih atau langsung menimbulkan kematian, dan semata-mata disebabkan oleh gangguan aliran darah otak non-traumatik. Jenis penelitian ini adalah penelitian eksperimental dengan rancangan one group pretest dan posttest. Penelitian dilakukan pada Ruang Rindu A4 RSUP Haji Adam Malik Medan, yang dilaksanakan mulai bulan Desember 2013 sampai dengan Mei 2014 dengan populasi 87 orang. Teknik pengambilan sampel dengan cara accidental sampling yaitu pengambilan sampel yang dilakukan dengan kebetulan bertemu yang berjumlah 12 responden. Hasil penelitian diketahui bahwa kekuatan otot ekstremitas atas pada pasien stroke non hemoragik sebelum dilakukan latihan Range Of Motion (ROM) pasif memiliki tingkat kekuatan otot yang sangat kecil, kekuatan otot ekstremitas atas pada pasien stroke non hemoragik sesudah dilakukan latihan Range Of Motion (ROM) pasif, terjadi perbaikan atau peningkatan. Adanya pengaruh yang signifikan antara sebelum dilakukan latihan Range of Motion (ROM) pasif, terjadi perbaikan atau peningkatan dan adanya pengaruh yang signifikan antara sebelum dilakukan latihan Range Of Motion (ROM) pasif dan setelah tujuh hari pemberian latihan Range Of Motion (ROM) pasif. Hal ini perlu ditingkatkan dengan memberikan latihan lebih lama minimal 4 minggu. Setelah itu, perlu diidentifikasi faktor-faktor apa saja yang mempengaruhi kekuatan otot pasien stroke.
\end{abstract}

Kata Kunci : Kekuatan otot ekstremitas, stroke

\section{PENDAHULUAN}

Stroke merupakan syndrom klinis yang awal timbulnya mendadak, progresif, berupa defisit neurologis fokal dan atau global yang berlangsung 24 jam atau lebih atau langsung menimbulkan kematian, dan semata-mata disebabkan oleh gangguan aliran darah otak non-traumatik (Arief, 2000). Stroke adalah penyakit neurologis terbanyak yang dapat mengakibatkan masalah kesehatan yang serius dan berdampak pada kecacatan, kematian, dan ekonomi keluarga, akibat dari adanya disfungsi motorik dan sensorik (Subianto, 2012)

Pasien dengan stroke akan mengalami gangguan-gangguan yang bersifat fungsional. Gangguan sensoris dan motorik post stroke mengakibatkan gangguan keseimbangan termasuk kelemahan otot, penurunan fleksibilitas jaringan lunak, serta gangguan kontrol motorik dan sensorik. Fungsi yang hilang akibat gangguan kontrol motorik pada pasien stroke mengakibatkan hilangnya koordinasi, hilangnya kemampuan keseimbangan tubuh dan postur (kemampuan untuk mempertahankan posisi tertentu) (Irfan, 2010 Santoso \& Ali, 2013).

Pasien stroke yang mengalami kelumpuhan di Indonesia sekitar 56,5\%. Stroke pada orang dewasa akan berdampak menurunnya produktivitas dan menjadi beban berat bagi keluarga, sehingga penderita stroke diharuskan mampu untuk beradaptasi dengan kondisi akibat stroke (Sutrisno, 2007 Murtaqib, 2013).

Menurut World Health Organization (WHO), pada tahun 2001 ada 20,5 juta jiwa di dunia terkena stroke. Penyakit tekanan darah tinggi atau hipertensi menyumbangkan 17,5 juta kasus stroke di dunia. Di Amerika Serikat, stroke menempati posisi ketiga, dimana setiap tahun dilaporkan 700.000 kasus stroke. Sebanyak 500.000 di antaranya kasus serangan pertama, sedangkan 200.000 kasus lainnya berupa serangan stroke berulang (Sutrisno, 2007). Badan Kesehatan Dunia (WHO) memprediksi bahwa kematian akibat stroke meningkat seiring dengan kematian akibat penyakit jantung dan kanker kurang lebih 6 juta pada tahun 2010 menjadi 8 juta di tahun 2030 (Wayan, 2012).

Di Indonesia penyakit ini menduduki posisi ketiga setelah jantung dan kanker. Sebanyak 28,5\% penderita stroke meninggal dunia. Sisanya menderita kelumpuhan sebagian maupun total. Yayasan Stroke Indonesia (Yastroksi) menyebutkan bahwa 63,52 per 100.000 penduduk Indonesia berumur di atas 65 tahun diperkirakan terkena stroke. Survey ASEAN Neurological Association (ASNA) penelitian di 28 Rumah Sakit seluruh Indonesia menyebutkan bahwa penderita laki-laki lebih banyak dari perempuan dan 
profil usia dibawah 45 tahun cukup banyak yaitu $11,8 \%$, usia 45-64 tahun berjumlah 54,2\% dan diatas usia 65 tahun 33,5\% (Rasyid, 2011). Prevalensi Stroke tertinggi ada di Kabupaten Nias Selatan yaitu 9,6\% dan terendah di Kabupaten Serdang Bedagai yaitu 2,4\% (Riskerdas 2007, Depkes 2008).

Penderita stroke yang mengalami kelemahan otot dan tidak segera mendapatkan penanganan yang tepat dapat menimbulkan komplikasi, salah satunyaadalah kontraktur. Kontraktur menyebabkan terjadinya gangguan fungsional, gangguan mobilisasi, gangguan aktivitas sehari-hari dan cacat yang tidak dapat disembuhkan (Asmadi, 2008). Angka kecacatan akibat stroke umumnya lebih tinggi daripada angka kematian, perbandingan antara cacat dankematian adalah 4:1. Menurut Pusat Data dan Informasi PERSI, stroke menempati urutan pertama dalam hal penyebab kecacatan fisik (Persi, 2001 Murtaqib, 2013).

Meskipun upaya pencengahan telah dilakukan namun insiden dengan laju mortalitas $18 \%$ sampai $37 \%$ untuk stroke pertama dan sebasar $62 \%$ untuk stroke selanjutnya. Terdapat kira-kira 2 juta orang bertahan hidup dari stroke yang mempunyai beberapa kecacatan; dari angka ini, 40\% memerlukan bantuan dalam beraktivitas dalam kehidupan sehari-hari.

Pasien stroke yang mengalami keterbatasan mobilisasi tidak mampu melakukan beberapa atau semua latihan rentang gerak dengan mandiri. Keterbatasan ini dapat identifikasi pada klien yang pada salah satu ekstremitas mempunyai keterbatasan gerakan atau klien yang mengalami imobilisasi seluruhnya. Latihan rentang gerak dapat aktif (klien menggerakkan semua sendinya dengan rentang gerak tanpa bantuan), pasif (klien tidak dapat menggerakkan dengan mandiri dan perawat menggerakkan setiap sendi dengan rentang gerak). Pemberian terapi latihan berupa gerakan pasif sangat bermanfaat dalam menjaga sifat fisiologis dari jaringan otot dan sendi (Potter \& Perry, 2006). Banyak efek samping yang menyertai stroke, misalnya depresi. Pasien cenderung berubah jadi murung, putus asa, sedih, dan kecewa. Mereka merasa tidak punya harapan hidup lagi karena sejumlah keterbatasan yang dimiliki. Jika kesedihan itu terus berlanjut, dan tidak diisi dengan menjalani rehabilitasi, kondisi pasien akan semakin buruk. Ia bisa menyendiri di kamar dan melakukan bunuh diri. Selain itu, tingkat kecacatan bakal menjadi parah. Organ-organ yang lumpuh bertambah banyak. Organ yang semula masih bisa diperbaiki menjadi lumpuh dan tak dapat dinormalkan kembali, khususnya anggota gerak. Jika tidak dijaga, akan menyebabkan atrofi otot-otot anggota gerak. Hal ini perlu diperhatikan.

Jenis penelitian dapat diberikan sedini mungkin untuk menghindari adanya komplikasi akibat kurang gerak serta mencegah otot yang tidak digunakan secara berlebihan, atrofi, kontraktur sendi. Pemberian terapi latihan ini sangat bermanfaat, sehingga dianjurkan untuk mengapilikasinya pada pasien stroke (Kwakkel, 2004). Pemberian terapi secara terpadu dan sedini mungkin maka semakin besar kemungkinan pengembalian fungsi, juga komplikasi akibat imobilisasi dapat dicegah dan kecacatan lebih lanjut dapat dihindari sehingga dapat mandiri tanpa tergantung pada orang lain. (Bethesda,2008).

Salah satu rehabilitasi tersebut adalah latihan rentang gerak atau Range Of Motion (ROM). Range Of Motion (ROM) adalah latihan yang dilakukan untuk mempertahankan atau memperbaiki tingkat kesempurnaan kemampuan menggerakkan persendian secara normal dan lengkap untuk meningkatkan massa otot dan tonus otot. Banyak faktor-faktor yang mempengaruhi peningkatan kekuatan otot dalam pemberian latihan Range Of Motion (ROM), beberapa diantaranya adalah usia, jenis kelamin, dan frekuensi serangan.

Dari hasil penelitian yang dilakukan oleh Vica Melsa Rahmi di RSUP H Adam Malik Medan 2012, terdapat peningkatan kekuatan otot yang dilakukan pada 10 pasien dengan rata-rata peningkatan otot meningkat antara intervensi $(0,30)$ dan sesudah intervensi $(1,80)$ dan dari hasil penelitian sebelumnya dilakukan Maria Astrid di Rumah Sakit Saint Carolus Jakarta Tahun 2011, terdapat peningkatan kekuatan otot meningkat antara antara intervensi $(2,93)$ dan sesudah intervensi (4,2) (Rahmi, 2012). Rehabilitasi penderita stroke yang digunakan adalah gerakan pasif denggan menggerakkan sendi-sendi pasien untuk mencegah terjadinya atrofi otot gerak.

Di Rumah Sakit Cipto Mangunkusumo (RSCM) misalnya, rehabilitasi yang tepat bisa menurunkan persentase angka kematian akibat stroke dari $40 \%$ menjadi 25\%, bahkan di Unit Pelayanan Khusus Stroke Soeparjdo Roestam unit swadana RSCM bisa ditekan hingga 13 persen (Sutrisno, 2007).

Penderita stroke harus dimobilisasi sedini mungkin ketika kondisi klinis neurologis dan hemodinamik penderita sudah mulai stabil. Mobilisasi dilakukan secara rutin dan terus menerus untuk mencegah terjadinya komplikasi stroke, terutama kontraktur. Latihan ROM merupakan salah satubentuk latihan dalam proses rehabilitasi yang dinilai cukup efektif untuk mencegah terjadinya kecacatan pada penderita stroke. Latihan ini adalah salah satu bentuk intervensi fundamental perawat yang dapat dilakukan untuk keberhasilan regimen terapeutik bagi penderita dan dalam upaya pencegahan terjadinya kondisi cacat permanen pada penderita stroke paska perawatan di rumah sakit, sehingga dapat menurunkan tingkat ketergantungan penderita pada keluarga, meningkatkan harga diri dan mekanis mekoping penderita. Lewis (2007) mengemukakan bahwa sebaiknya latihan pada penderita stroke dilakukan 2 kali dalam sehari untuk mencegah komplikasi, semakin dini proses rehabilitasi di mulai, maka kemungkinan penderita mengalami defisit kemampuan akan semakin kecil. Penelitian menunjukan bahwa latihan ROM dapat meningkatkan fleksibilitas danrentang gerak sendi. Latihan ROM dilakukan selama 1 minggu dan 2 minggu, 1 hari 2 kali yaitu pagi dan sore selama 10-15 menit, maka memiliki kesempatanuntuk mengalami penyembuhan dengan baik (Murtaqib, 2013).

Data yang diperoleh dari RSUP. Haji Adam Malik Medan, jumlah penderita stroke yang dirawat 
inap Tahun 2011 berjumlah 421 orang, pada Tahun 2012 berjumlah 448, dan pada Tahun 2013 berjumlah 474 orang. Setelah dilakukan observasi pada 6 pasien tingkat kekuatan otot pasien tersebut menurun dan kemampuan mereka beraktivitas rendah.

Berdasarkan latar belakang tersebut penulis tertarik untuk melakukan penelitian tentang pengaruh latihan ROM pasif terhadap kekuatan otot ekstremitas pada pasien stroke di ruang RA4 RSUP H Adam Malik Medan.

\section{METODE PENELITIAN}

Jenis penelitian ini adalah penelitian eksperimental dengan rancangan one group pretest dan posttest. Lokasi penelitian di Ruang Rindu A4 RSUP Haji Adam Malik Medan, dan dilaksanakan pada bulan Desember 2013 sampai dengan Mei 2014. Populasi pada penelitian ini adalah seluruh pasien rawat inap Stroke Non Hemoragik di Ruang RA4 mulai bulan Oktober sampai Desember berjumlah 87 orang. Teknik pengambilan sampel dalam penelitian ini adalah dengan cara accidental sampling yaitu pengambilan sampel yang dilakukan dengan kebetulan bertemu (Alimul, 2009). Sampel dalam penelitian ini berjumlah 12 responden.

Data diperoleh melalui data primer atau data langsung yang diperoleh saat penelitian, selain itu peneliti juga menggunakan data sekunder yang didapat dari sumber-sumber yang ada diruang rawat inap medical record RSUP Haji Adam Malik Medan. Data kemudian dianalisa dengan menggunakan analisa univariat untuk mengetahui hasil distribusi dan persentase dari setiap variabel dan bivariat untuk melihat pengaruh antar variabel bebas (latihan ROM pasif) dengan variabel terikat (kekuatan otot), maka uji yang digunakan adalah uji $\mathrm{t}$ dependen yang sering disebut paired t-test, dengan tingkat keprcayaan $95 \%$, bila nilai $\rho<0,05$, maka Ho ditolak dan jika $\rho>0,05$, maka Ha diterima.

\section{HASIL PENELITIAN DAN PEMBAHASAN}

\section{Hasil}

\section{Univariat}

Dari hasil observasi terhadap responden dengan pengaruh latihan (ROM) pasif terhadap kekuatan otot ekstremitas pada pasien stroke di Ruang RA4 RSUP H. Adam Malik Medan Tahun 2014 berdasarkan jenis kelamin sebanyak 8 responden (67) laki-laki, 4 responden $(33 \%)$ perempuan. Berdasarkan usia responden dengan usia 45-65 tahun sebanyak 6 responden (50\%) sedangkan responden dengan usia $<45$ dan $>65$ tahun masing-masing sebanyak 3 responden (25\%), dan usia 45-65 tahun 6 responden $(50 \%)$. Berdasrkan pekerjaan, responden bekerja sebagai IRT sebanyak 4 responden (33\%), buruh/petani 1 responden (8\%), wiraswasta 5 responden (42\%) dan PNS 2 responden (17\%). Berdasarkan suku responden dengan suku Aceh sebanyak 2 responden (17\%), suku Batak 5 responden (41\%), suku Jawa 2 responden $(16 \%)$ dan suku Karo 3 responden (25\%). Berdasarkan frekuensi serangan responden dengan serangan pertama sebanyak 8 responden $(66 \%)$, serangan kedua 4 responden $(34 \%)$. Berdasarkan lama perawatan responden dengan lama perawatan 2 minggu sebanyak 8 responden (66\%), 3 minggu 4 responden (33\%).

Berdasarkan tingkat kekuatan otot sebelum dilakukan latihan Range of Motion (ROM) pasif, responden dengan tingkat kekuatan otot 1 sebanyak 8 responden $(67 \%)$ dan tingkat kekuatan otot 2 sebanyak 4 responden (33\%). Berdasarkan tingkat kekuatan otot sesudah dilakukan latihan Range of Motion (ROM) pasif, responden dengan tingkat kekuatan otot 1 sebanyak 2 responden (17\%), tingkat kekuatan otot 2 sebanyak 3 responden (25\%) dan tingkat kekuatan otot 3 sebanyak 7 responden $(58 \%)$.

Hasil pengukurun responden berdasarkan tingkat kekuatan otot ekstremitas atas pada responden 1,3,9 sebelum dilakukan latihan Range Of Motion (ROM) Pasif tingkat kekuatan ototnya masing-masing nilai 1 sesudah dilakukan latihan masing-masing meningkat menjadi nilai 3. Pada responden 2,7,12 sebelum dilakukan latihan Range Of Motion (ROM) Pasif tingkat kekuatan ototnya masingmasing nilai 1 sesudah dilakukan latihan masing-masing meningkat menjadi nilai 2. Pada responden 4,6,8,10 sebelum dilakukan latihan Range Of Motion (ROM) Pasif tingkat kekuatan ototnya masing-masing nilai 2 sesudah dilakukan latihan masing-masing meningkat menjadi nilai 3. Sedangkan responden 5 dan 11 sebelum dan sesudah dilakukan latihan Range Of Motion (ROM) Pasif nilainya masih tetap 1 , tidak mengalami peningkatan.

\section{Bivariat}

Dari hasil penelitian, sebelum dilakukan Range Of Motion (ROM) pasif pada pasien stroke non hemoragik, kekuatan otot ekstremitas atas responden menunjukkan nilai kekuatan otot yang kecil dengan nilai 1-2. Namun setelah dilakukan latihan Range Of Motion (ROM) pasif pada seluruh responden, terjadi peningkatan kekuatan otot ekstremitas atas yang didominasi dengan nilai kekuatan otot 3 .

\section{Pembahasan}

Dari hasil penelitian ini peneliti menemukan bahwa $\rho=0,068$, berarti Ho ditolak dan Ha diterima, yang artinya ada pengaruh latihan Range Of Motion (ROM) pasif terhadap peningkatan kekuatan otot ekstremitas atas pada pasien stroke non hemoragik. Hasil penelitian ini sesuai dengan Astrid (2011), yang menyatakan ada pengaruh latihan Range Of Motion (ROM) pasif terhadap peningkatan kekuatan otot.

Selain itu, karakteristik demografi responden sangat mempengaruhi peningkatan kekuatan otot. Kekuatan otot sebelum dilakukan latihan Range Of Motion (ROM) pasif pada usia 45-65 tahun sebesar 50\% hal ini disebabkan karena penurunan aktivitas yang dapat menyebabkan timbulnya kelemahan otot serta atrofi. Dan terjadi peningkatan otot setelah dilakukan latihan Range Of Motion (ROM) pasif kekuatan otot 2 menjadi kekuatan otot 3. Dan pada usia $<45$ tahun terjadi peningkatan kekuatan otot yang signifikan dari kekuatan otot 1 menjadi kekuatan otot 3. Kekuatan otot pada pria lebih besar $25 \%$ dari pada wanita. Hal ini terjadi akibat pria memiliki 
hormon testosterone yang merupakan anabolic steroid. Pada penelitian ini kekuatan otot pada laki-laki dari 1 menjadi $3(66,7 \%)$. Pada wanita kekuatan otot 2 menjadi kekuatan otot $3(33,3 \%)$. Pada peningkatan kekuatan otot untuk suku terbanyak adalah suku batak dari kekuatan otot 1 menjadi kekuatan otot $3(41,7 \%)$. Hal ini dikarenakan suka batak lebih temperamen dari suku-suku lainnya, sehingga mempercepat peningkatan kekuatan otot. Peningkatan kekuatan otot sangat dipengaruhi frekuensi serangan. Frekuensi serangan pertama terjadi peningkatan kekuatan otot antara kekuatan otot 1 menjadi kekuatan otot $3(66,7 \%)$.

Peningkatan kekuatan otot sangat berpengaruh bila banyak beraktivitas. Dari penelitian ini peningkatan kekuatan otot terjadi pada wiraswasta karena wiraswasta lebih banyak beraktivitas. Peningkatan kekuatan otot dari antara 1 menjadi kekuatan otot $3(33,3 \%)$

Menurut pendapat Smeltzer \& Bare (2002), bahwa regulitas dalam latihan bagi pasien stroke merupakan hal yang paling penting karena perbaikan kekuatan otot dan pemeliharaan rentang gerak dapat dicapai hanya melalui latihan harian.

\section{KESIMPULAN DAN SARAN}

Dari hasil penelitian ini dapat disimpulkan bahwa kekuatan otot ekstremitas atas pada pasien stroke non hemoragik sebelum dilakukan latihan Range Of Motion (ROM) pasif memiliki tingkat kekuatan otot yang sangat kecil. Kekuatan otot ekstremitas atas pada pasien stroke non hemoragik sesudah dilakukan latihan Range Of Motion (ROM) pasif, terjadi perbaikan atau peningkatan. Adanya pengaruh yang signifikan antara sebelum dilakukan latihan Range of Motion (ROM) pasif, terjadi perbaikan atau peningkatan. Adanya pengaruh yang signifikan antara sebelum dilakukan latihan Range Of Motion (ROM) pasif dan setelah tujuh hari pemberian latihan Range Of Motion (ROM) pasif.

Disarankan bagi perawat untuk memberikan latihan Range Of Motion (ROM) pasif kepada pasien stroke yang mengalami kelemahan otot secara teratur dalam bentuk latihan dua kali sehari selama 15-30 menit dengan pengulangan empat kali setiap gerakan. Karena terbukti berpengaruh terhadap peningkatan kekuatan otot pasien. Kepada Instalansi Rumah Sakit perlu memasukkan latihan Range Of Motion (ROM) pasif kedalam prosedur tetap dalam perawatan pasien stroke, karena latihan Range Of Motion (ROM) pasif. Terbukti meningkatkan kekuatan otot pasien. Dan bagi peneliti selanjutnya diharapkan waktu pemberian latihan lebih lama minimal 4 minggu. Setelah itu, perlu diidentifikasi faktor-faktor apa saja yang mempengaruhi kekuatan otot pasien stroke.

\section{DAFTAR PUSTAKA}

Alimul A. 2009. Metode Penelitian Keperawatan dan Tehnik Analisa Data.Salemba Medika: Jakarta.

Al Diwanto, Masde. 2009. Tips Mencegah Stroke, Hipertensi dan SeranganJantung. Paradigma Indonesia: Yogyakarta.
Astrid Maria. 2011. Pengaruh Latihan Range Of Motion (ROM) Terhadap Kekuataan Otot, Luas Gerak Sendi dan Kemampuan Fungsional Pasien Stroke.

Bethesda. 2008. Terapai Latihan. Available from: www.repository.usu.ac.id/bitstream/123456789/312 12/7/cover.pdf

Bustan M. N. 2007. Epidimiologi: Penyakit Tidak Menular, cetakan 2,Rhineka Cipta: Jakarta

Depkes. 2010. Kekuataan Otot.Available from: www.depkes.go.id

Kusyati, Eni. 2006. Keterampilan dan Prosedur Laboratorium. EGC:Jakarta

Lumbantobing. S. M. 2007. Stroke Bencana Peredaran Darah di Otak. FKUI: Jakarta.

Mulyatsih Enny \& Ahmad A. 2010. Stoke Petunjuk Perawatan Pasien Pasca Stroke di Rumah. FKUI: Jakarta

Muttaqin, 2008. Asuhan keperawatan Klien Dengan Gangguan Sistem Persarafan. Salemba Medika: Jakarta

Murtaqib, 2013. Latihan Range Of Motion (ROM) Pasif Dan Aktif Selama 1-2 Minggu Terhadap Perbedaan Peningkatan Rentang Gerak Sendi Pada Penderita Stroke Di Kecamatan Tanggul Kabupaten Jember, Universitas Jember

Notoatmodjo, Soekidjo. 2010. Metode Penelitian Kesehatan. Rhineka Cipta: Jakarta.

Potter, P. A \& Perry, A. G. 2006. Fundamental Keperawatan: Konsep, Proses, dan Praktik. EGC: Jakarta.

Santoso \& Ali, 2013. Perbedaan Efektivitas ROM Aktif Dengan ROM Aktif Asistif (Spherical Grip) Terhadap Kekuatan Otot Ekstremitas Atas Pada Pasien Stroke Non hemoragik DiKecamatan Karanganyar Kabupaten Pekalongan. Sekolah Tinggi Ilmu Kesehatan Muhammadyah Pekajangan Pekalongan

Shadine, Mahannad, 2010. Mengenal Penyakit Hipertensi, Diabetes, Stroke \& Serangan Jantung. Keen Books: Jakarta

Simatupang D. 2011. Jurnal PANNMED, vol 6 no 2. USU press: Medan

Smeltzer, S. C. Dan Bare. B. G. 2002. Buk ran Keperawatan Medikal Bedah Brun ind Suddarth, Edisi 8 vol 1. EGC: Jakarta

Smeltzer, S. C. Dan Bare. B. G. 2002. Buku Ajaran Keperawatan Medikal Bedah Brunner and Suddarth, Edisi 8 vol 3. EGC: Jakarta.

Subianto, Rendra 2012 Pengaruh Latihan ROM (Range Of Motion) Terhadap Mobilisasi Pada Pasien Stroke, Universitas Muhamaddiyah Ponorogo

Sutanto. 2010. Cekal Penyakit Modern. Andi Offset: Yogyakarta

Sutrisno, Alfred. 2007. Stroke???? Gramedia Pustaka Umum: Jakarta.

Wayan, 2012.Pengaruh Latihan Range Of Motion (ROM) Pasif Terhadap Peningkatan Kekuatan Otot Ekstremitas Atas Pada pasien Stroke Non Hemoragik. 